\title{
The benefits, synergies and conflicts of green design in urban policy, a case study of Kosice city
}

\author{
Zuzana Poorova ${ }^{1, *}$ and Zuzana Vranayova $^{2}$ \\ ${ }^{1}$ Faculty of Civil Engineering, Technical University of Kosice, Vysokoskolska 4, Kosice 04001 \\ ${ }^{2}$ Faculty of Civil Engineering, Technical University of Kosice, Vysokoskolska 4, Kosice 04001
}

\begin{abstract}
The end of climate change must begin with cities. $75 \%$ of Europe's population chooses the city as a place to reside. How does one maximize the supply of fresh air and provide enough green areas for builtup areas? Cities are growing fast, strengthening the effects of thermal islands by sealing the spaces, removing natural habitats and creating heat. The principle of green design is a response to many questions. But the question remains, what is green design? Designing healthy cities, bringing nature, greenery and water into urban areas, covering building roofs with soil, integrating wilderness, building green roofs and walls, water retention and recycling? The paper explains the problematic new term "sponge city" using a case study of the green roofs in Kosice.
\end{abstract}

\section{Introduction}

In the context of the growing number of inhabitants within the city's structures, the faces of settlements are changing. Without words, we accept the changes, destroying squares and city centers, stopping impeding playgrounds and green areas. Greenery and trees are being pushed further away from us on the periphery. We set back the once-decisive public spaces. [1].

Climate changes have become rather less noticed; therefore we take note of them less. Deborah J. Nelson, winner of the Pulitzer Prize for Journalism, calls attention to it in her work. "Climate change is one of the biggest catastrophes humans are facing. However it is coming slowly, so it is taking the media very long time to get it noticed. The journalists do not know how to write about environmental issues. The media have noticed this topic, but they mostly focus on the most terrifying predictions about what awaits the Earth in next hundred years. This is of course very important and it needs to be regularly reminded in public, but it is also good to make people think about global warming when it is perceived only as only as a threat. For industry and deniers of climate change it is much easier to sow doubts whether the predictions are really real." To her, it seemed important to look in the opposite direction, back, to the last century and document climatic changes that have already occurred. To show what is happening here and now. Not only globally, but directly

\footnotetext{
*Corresponding author: zuzana.poorova.tuke@gmail.com
} 
to people next to us. If people see what is already happening, they do not have to imagine, what should happen in the future, it will be taken seriously [2].

The analysis of a heat island includes data from numerous fixed stations in and around the city. If enough stations are available, a two-dimensional contour map of the city's temperatures can be generated [1]. In this paper the ongoing research of Kosice heat island is described.

\section{Extremes in 2015}

According to a five-year analysis, the World Meteorological Organization (WMO) stated that the period between 2011 and 2015 was the warmest period of a five-year long period in the history of observations. During this period there have been many cases of extreme weather, particularly heat waves. The situation of the global climate in 2015 was historic for many reasons. The level of greenhouse gases in the atmosphere had reached new highs in the northern hemisphere during the spring of 2015. For the first time it exceeded a 3 month average of global concentrations of $\mathrm{CO}_{2} .2015$ was the warmest year in the history records in terms of the surface temperature of the oceans since the beginning of observations [3].

The summer of 2016 was in all the main features quite different than the summer of 2015. While the year 2015 was extremely warm, at the same time it was also very dry. The summer of 2016 was much wetter than the summer of 2015. This resulted in a high number of days and nights where people felt stuffy. It also resulted in intense thunderstorms. An essential feature of the summer of 2016 was also part of the transition significant cold front, which also initiated a significant convective systems that brought abundant rainfall. That is why in 2016 we did not observe similar long periods of high daily maximum air temperatures exceeding $35{ }^{\circ} \mathrm{C}$ as in the summer of 2015 . Characteristic features of the summer of 2016 were extremely a high temperatures and high frequency of intense storms and torrential rainfalls that are associated with them $[4,5]$.

Following the above-mentioned information from July 01-31, 2015 data were used to create a map of the heat island, as well as a map of green roofs of Kosice which lead to the application of sponge city features.

\section{Weather stations}

The research uses only weather stations listed in Table1. The study takes into account only the parameters given by these stations. For further research on this topic, more parameters will be needed to complete it.

\section{Data}

Table 1. Maximum temperature and minimum humidity trends in 07/2015.

\begin{tabular}{c|c|c}
\hline address & max. temperature $\left[{ }^{\circ} \mathrm{C}\right]$ & min. humidity [\%] \\
\hline Berlínska 3 & 41.1 & 22 \\
\hline Branisková 25 & 36.6 & 25 \\
\hline Brnenská 41 & 39.6 & 21 \\
\hline Bukovecká 43 & 42.7 & 20 \\
\hline Bukovecká 68 & 38.4 & 22 \\
\hline Cesta pod Hradovou 6 & 31.4 & 29 \\
\hline
\end{tabular}




\begin{tabular}{c|c|c} 
Čingovská 15 & 32.4 & 41 \\
\hline Čingovská 72 & 36 & 25 \\
\hline Magnezitárska 2 & 37.8 & 24 \\
\hline Fatranská 39 & 37.9 & 19 \\
\hline Hrabová 8 & 43.4 & 26 \\
\hline Kmetova 51 & 35.4 & 28 \\
\hline Komenského 56 & 33.8 & 22 \\
\hline Obrodv 63 & 38.4 & 26 \\
\hline Park angelium 58 & 35.1 & 27 \\
\hline Park mládeže 4 & 34.2 & 17 \\
\hline Severné Nábrežie 30 & 45.1 & 18 \\
\hline Sokolovská 23 & 47.6 & 27 \\
\hline Starozagorská 5 & 46.5 & 21 \\
\hline Šuhaiova 49 & 34.3 & 24 \\
\hline Šuhaiova 70 & 40.5 & 22 \\
\hline Turgenevova 66 & 37 & 19 \\
\hline Zinková 9 & 37.8 &
\end{tabular}

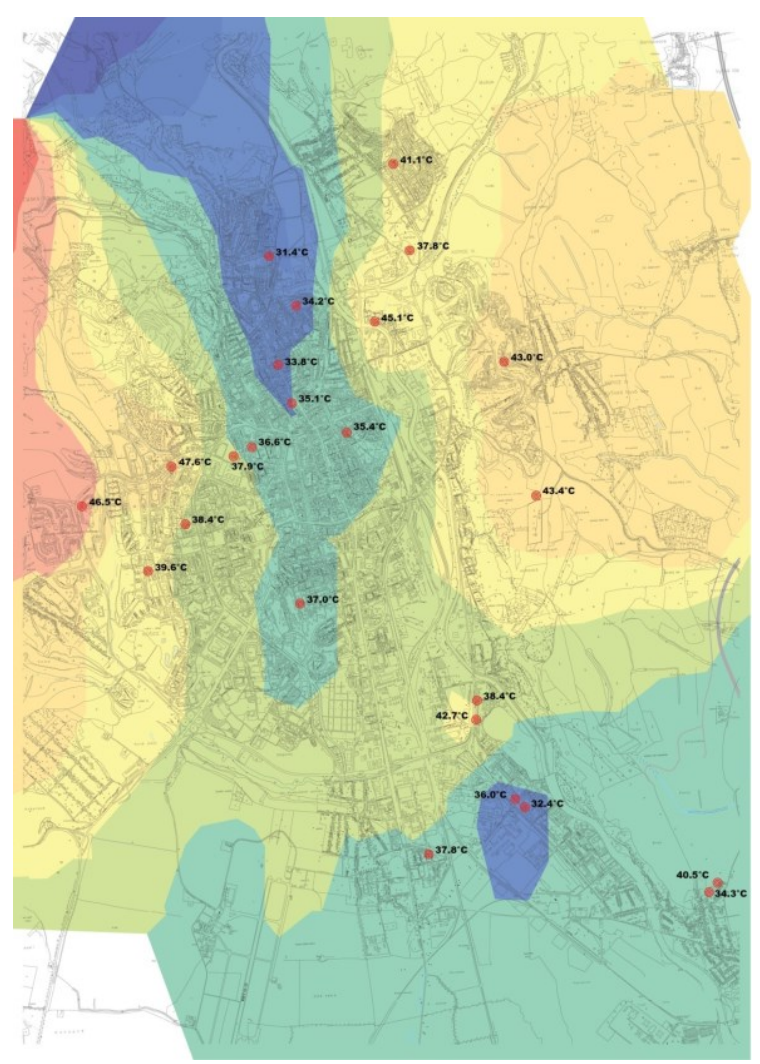

Fig. 1. Spatial distribution of temperature trends in July 2015 in Kosice. 


\subsection{Max. temperatures}

Studies on urban heat islands in other cities of world are focusing on air temperatures rather than focusing on surface temperatures as a first factor. There are several types of heat islands depending on the climate and topography [6].

This study also focuses on air temperatures, following study of efficiency of green roofs to mitigate urban heat island effect in Rio de Janeiro [6]. Online data from the period July 01-31, 2015 (bold text) were supplemented with calculated data (regular text) caused by gaps in measurement, using data from the period July 01-31, 2016, mathematic calculation and taking into account the location of the weather station.

The study uses maximum temperatures, because it takes the worst case scenario into account. The spatial distribution of temperature trends in July 2015 in Kosice is presented in Figure 1. The distribution of temperature trends used only data (max. temperature $\left[{ }^{\circ} \mathrm{C}\right]$ ) listed in Table 1.

In Kosice during the summer of 2015 , up to $15.2^{\circ} \mathrm{C}$ temperature differences (minimum $32.4^{\circ} \mathrm{C}$, maximum $47.6^{\circ} \mathrm{C}$ ) occurred when comparing one housing estate to another housing estate. The biggest extremes are observed in the Nad Jazerom and Krásna housing estates (Table 2). The differences are due to the presence of a heatning station, lake and park near weather stations used for this research.

\subsection{Calculating max. temperatures}

Modelling and analysing tools of ArcGIS - Geostatistical Analyst - in the modelling of spatial distribution of temperature trends were used. Geostatistics is based on the regionalization of the random variable in a given area. A set of random variables generated the random function. The random function model is based on a study of the spatial variability of the studied phenomenon in different directions - experimental variogram. The result of this study is a mathematical model of the variogram defined by changing the spatial variability in different directions of space by anisotropy and autocorrelation. The calculation of the empirical semivariogram is written in the form [6]:

$$
\gamma(h)=\frac{1}{2 n(h)} \sum_{i=1}^{n(h)}\left[z\left(s_{i}\right)-z\left(s_{i}+h\right)\right]^{2}
$$

where: $\gamma(h)$ is the estimated semivariation for the distance $h n(h)$ is the number of pairs of measured points separated by a distance; and $\mathrm{h} ; z\left(s_{i}\right)$ is a measured value in point $\left(s_{i}\right)$.

The first step is the calculation of the empirical semivariogram, followed by the transfer of the empirical semivariogram by its theoretical model and determining its parameters. The model found for a given set of data depends on the experimental and theoretical assumptions.

The determining of semivariogram parameters is followed by the actual process of estimating the phenomenon of unknown values based on known data - Kriging [6].

The detail of the spatial distribution of temperature trends in July 2015 in Kosice focusing on city centre is presented in Figure 2.

Table 2. Range of maximum temperature trends in 07/2015.

\begin{tabular}{l|l|l|l|l|l|l|l|l|l}
\hline address & 30 & 32 & 34 & 36 & 38 & 40 & 42 & 44 & 46 \\
\hline Berlínska 3 & & & & & & & & & \\
\hline Branisková 25 & & & & & & & & & \\
\hline Brnenská 41 & & & & & & & & & \\
\hline Bukovecká 43 & & & & & & & & & \\
\hline Bukovecká 68 & & & & & & & & & \\
\hline Cesta pod Hradlovou 6 & & & & & & & & & \\
\hline
\end{tabular}




\begin{tabular}{l|l|l|l|l|l|l|l|l|l}
\hline Čingovská 15 & & & & & & & & & \\
\hline Čingovská 72 & & & & & & & & & \\
\hline Magnezitárska 2 & & & & & & & & & \\
\hline Fatranská 39 & & & & & & & & & \\
\hline Hrabová 8 & & & & & & & & & \\
\hline Kmet'ova 51 & & & & & & & & & \\
\hline Komenského 56 & & & & & & & & & \\
\hline Obrody 63 & & & & & & & & & \\
\hline Park angelium 58 & & & & & & & & & \\
\hline Park mládeže 4 & & & & & & & & & \\
\hline Severné Nábrežie 30 & & & & & & & & & \\
\hline Sokolovská 23 & & & & & & & & & \\
\hline Starozagorská 5 & & & & & & & & & \\
\hline Šuhajova 49 & & & & & & & & & \\
\hline Šuhajova 70 & & & & & & & & & \\
\hline Turgenevova 66 & & & & & & & & & \\
\hline Zinková 9 & & & & & & & & & \\
\hline Zupkova 7
\end{tabular}

\subsection{Min. humidity}

The spatial distribution of humidity trends in July 2015 in Kosice is displayed in Figure 3. The distribution of humidity trends used only data (min. humidity [\%]) listed in Table 1. The study uses minimum humidity as it takes the worst case scenario into account.

Table 3. Range of minimum humidity trends in 07/2015.

\begin{tabular}{c|l|l|l|l|l|l|l|l|l|l|l|l|l|l}
\hline address & 41 & 29 & 28 & 27 & 26 & 25 & 24 & 23 & 22 & 21 & 20 & 19 & 18 & 17 \\
\hline Berlínska 3 & & & & & & & & & & & & & & \\
\hline Branisková 25 & & & & & & & & & & & & & & \\
\hline Brnenská 41 & & & & & & & & & & & & & & \\
\hline Bukovecká 43 & & & & & & & & & & & & & & \\
\hline Bukovecká 68 & & & & & & & & & & & & & & \\
\hline Cesta pod Hradovou 6 & & & & & & & & & & & & & \\
\hline Čingovská 15 & & & & & & & & & & & & & & \\
\hline Čingovská 72 & & & & & & & & & & & & & \\
\hline Magnezitársa 2 & & & & & & & & & & & & & & \\
\hline Fatranská 39 & & & & & & & & & & & & & & \\
\hline Hrabová 8 & & & & & & & & & & & & & & \\
\hline Kmet'ova 51 & & & & & & & & & & & & & & \\
\hline Komenského 56 & & & & & & & & & & & & & & \\
\hline Obrody 63 & & & & & & & & & & & & & & \\
\hline Park angelium 58 & & & & & & & & & & & & & & \\
\hline Park mládeže 4 & & & & & & & & & & & & & \\
\hline Severné Nábrežie 30 & & & & & & & & & & & & & & \\
\hline Sokolovská 23 & & & & & & & & & & & & & & \\
\hline Starozagorská 5 & & & & & & & & & & & & & & \\
\hline Śuhajova 49 & & & & & & & & & & & & & & \\
\hline Šuhajova 70 & & & & & & & & & & & & & \\
\hline Turgenevova 66 & & & & & & & & & & & & & \\
\hline Zinková 9 & & & & & & & & & & & & & & \\
\hline Zupkova 7 & & & & & & & & & & & & & & \\
\hline
\end{tabular}


The detail of the spatial distribution of humidity trends in July 2015 in Kosice focusing on the city centre and surrounding housing estates is pictured in Figure 3 and Table 3.

The first radius of minimum humidity of each weather station represents 250 meters, the minimal distance between weather stations used for this research. The second radius represents 500 meters.

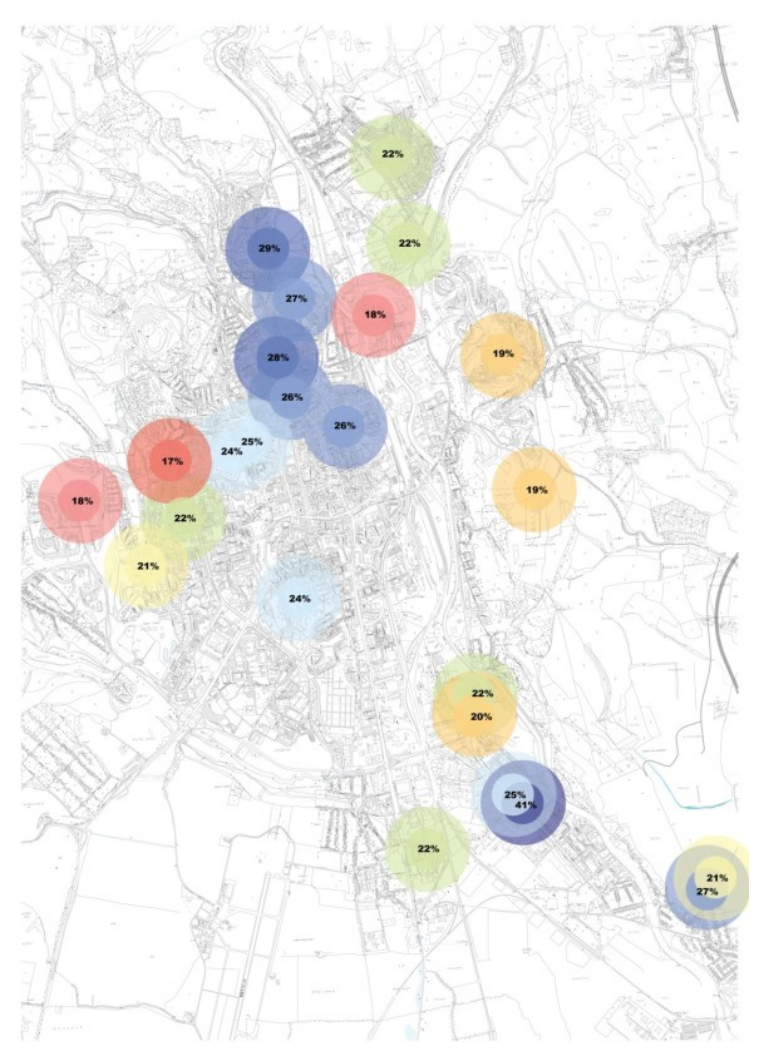

Fig. 2. Spatial distribution of humidity trends in July 2015 in Kosice - detail.

The distribution used only the data listed in Table 1. 22 self-governing neighborhoods have more than just one humidity zone. The largest extremes are observed in the Nad Jazerom and Krásna housing estates. The differences are due to the presence of a heating station, lake and park near the weather stations used for this research. Of importance is that these measurement results are related to the temperature measurements. The weather stations with the higher temperatures have lower humidity and the weather stations with lower temperatures have higher humidity. In Kosice during the summer of 2015 up to 24\% humidity differences (minimum 17\%, maximum 41\%) occurred in the comparison of one housing estate to another housing estate. 


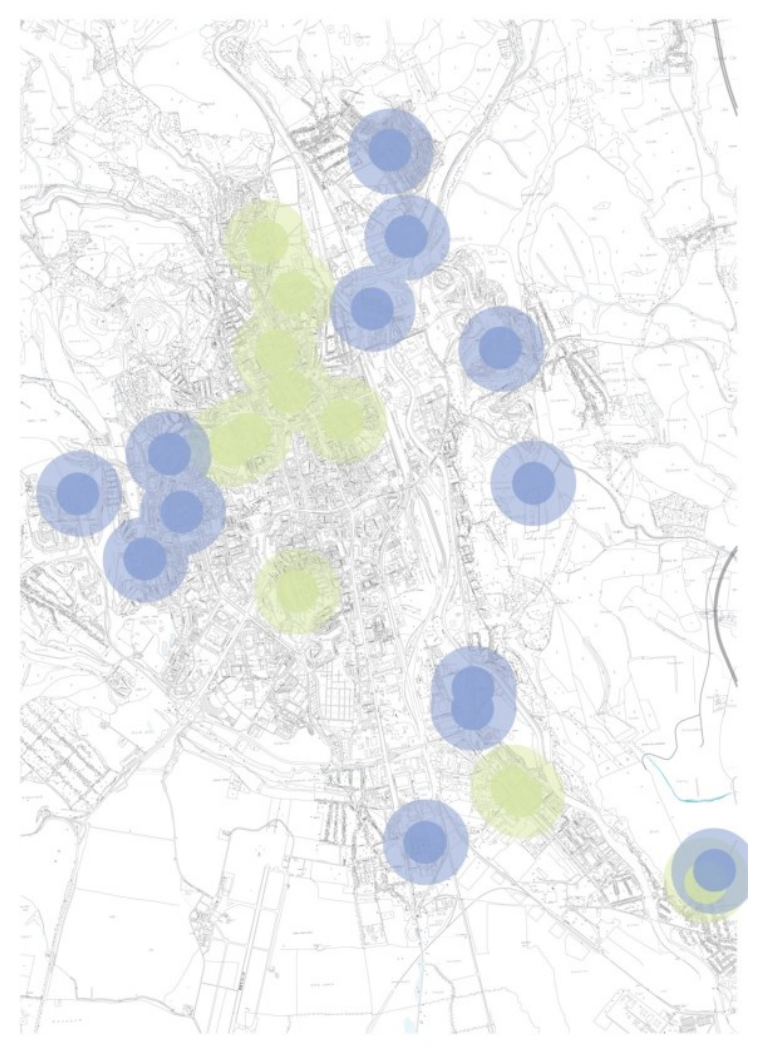

Fig. 3. Allocation of green roofs in Kosice following the spatial distribution of humidity trends.

\subsection{Calculating min. humidity}

The detail of spatial distribution of humidity trends in July 2015 in Kosice focusing on city centre and surrounding housing estates is pictured in Figure 3.

\section{Green roofs beating low humidity}

Kosice was chosen as a study area to demonstrate the possibility of beating low humidity and therefore the heat island in the city centre and housing estates implementing green roofs. The research deals with the possibility of using green roof structures to manage stormwater runoff delay, its reduction into the public drainage system and its storage for later reuse, therefore, changing a regular city into a sponge city.

Green roofs in urban areas are significant due to their capacity for water storage in the layers of the roof. This capacity and retention quality, allows minimizing the effect of extreme rainfall in a short period. Retaining water in the layers of a green roof means reducing the flood peak in the urban drainage system and reducing the risk of water distress.

A sponge city is a city that is designed to passively absorb, clean and use rainfall in an ecologically friendly way that reduces dangerous and polluted runoff. Associated techniques include permeable roads,rooftop gardens, rainwater harvesting, rain gardens, green space and blue space such as ponds and lakes. Properly implemented a sponge city can reduce the frequency and severity of floods, improve water quality and allow cities to 
use less water per person. Associated strategies such as green space, green wall or roof can also improve the quality of life, improve air quality and reduce urban heat islands.

\section{Conclusion}

The research uses 2 typical types of different green roof construction: those with low retention qualities and those with high retention qualities.

The area with low humidity (17-22\%) needs green roof construction with higher retention qualities (Figure 4, "blue colour"). The city area with higher humidity (24-41\%) needs green roof construction with lower retention qualities ("green color"). The map of green roofs in Kosice (Figure 4) is modeled using data in Table 1. The allocation of two different major types of "green colour roofs" and "blue colour roofs" of green roofs follows these data.

\section{References}

1. Gartland, L. (2011) Heat Islands. Undrestanding and Mitigating Heat in Urban Areas. London, Earthscan

2. Balogová, B. (2016) Klimatické zmeny sa nás dotýkajú už teraz, Korzár, 27.10.2016

3. Bochníček, O., Faško, P., Švec, M. (2016) Rok 2015 - druhý najteplejší v histórii meteorologických meraní v Európe (2015: second warmest in history of meteorological measurements in Europe) http://www.shmu.sk/sk/?page=2049\&id=681

4. Št’astný, P., Faško, P., Pecho, J., Labudová, L., Ivvaňáková, G., Kajaba, P., Turn̆, M, Bochníček, O. (2017) Rok 2016: mimoriadne teplý a vel'mi bohatý na atmosférické zrážky (Year 2016: extremely warm year with very rich in precipitations)

5. Siman, C., Pecho, J. (2017) Extrémne úhrny zrážok v závere júla 2016 (Extreme rainfall at the end of July 2016) http://www.shmu.sk/sk/?page=2049\&id=736

6. Konasova, S. (2016) The efficiency of green roofs to mitigate urban heat island effect in Rio de Janeiro Advances and Trends in Engineering Sciences and Technologies II Edited by Mohamad Al Ali and Peter Platko, Taylor \& Francis Group, 6000 Broken Sound Parkway NW, Suite 300, Boca Raton, FL 33487-2742 CRC Press 2016 SBN: 978-1-138-03224-8 http://www.crcnetbase.com/doi/abs/10.1201/9781315393827-80

7. Clark, I. (1979) Practical Geostatics http://www.kriging.com /PG1979/PG1979.pdf 